\title{
Comparative study of African catfish parasites from cultured and natural habitats
}

\author{
Olajide Joseph Afolabi", Fayokemi Christianah Olususi and Olusola Olasumbo Odeyemi
}

\begin{abstract}
Background: The study was conducted to compare parasitic loads of Clarias gariepinus from cultured and natural habitats. A total number of 80 live adults (200-799 g) C. gariepinus comprising of 20 each were randomly obtained from two cultured habitats (ponds) and two natural habitats (rivers). In the laboratory, these fish were all examined for the presence of parasites. Their sexes were identified while the lengths and weights were measured and recorded prior to dissection. The parasites observed were also identified using morphological characteristics.

Results: Out of the 80 C. gariepinus sampled, 43 (53.75\%) were infected and a total of 409 parasites comprising of 141 (34.47\%) ectoparasites and 268 (65.53\%) endoparasites were observed from the infected fish. The prevalence of parasitic infection in cultured and natural habitats was $20 \%$ and $33.75 \%$, respectively. The results showed that there was a significant difference $(P<0.05)$ in parasitic infection of $C$. gariepinus obtained from cultured and natural habitats. Parasitic loads were observed to be significantly higher in natural habitat (33.74\% and $26.16 \%$ for river $\mathrm{A}$ and river B, respectively) compared to cultured habitat ( $20.54 \%$ and $19.55 \%$ for pond A and pond B, respectively). The prevalence of parasites in relation to sexes of $C$. gariepinus was not significantly different $(P>0.05)$ for both habitats. It was also noted that catfishes with body weight 500-599 g had the highest prevalence (100\%) both in cultured and natural habitats.

Conclusions: The study showed that the parasite loads were more in C. gariepinus obtained from natural habitat compared to those obtained from cultured habitat. It is therefore recommended that the sanitary conditions under which fishes are reared in fish pond should be improved and fish stocked from natural habitats or unscreened ponds should be quarantined to eliminate and treat possible parasitic infection before introducing them into other fish ponds.
\end{abstract}

Keywords: Clarias gariepinus, Ectoparasites, Endoparasites, Fish ponds, Rivers

\section{Background}

Fish is a food commodity that is distributed worldwide and regarded as an important source of animal protein (Osuigwe and Obiekezie 2007) and other essential elements that are necessary for the maintenance of healthy body to the human especially in the developing countries. Fish on the average generally appear cheaper, and the protein contents of fish and its products are higher

\section{* Correspondence: ojafolabi@futa.edu.ng}

Department of Biology, Federal University of Technology Akure, Akure, Nigeria than those of other similar food items such as meat and eggs (Aihonsu et al. 2006). Fish is also an important source of income for fishermen and fish farmers especially in Nigeria and other developing countries (FAO 1996). It contributes significantly to the economic development of countries that involve in aquaculture and fisheries' programs.

The African catfish (Clarias garipienus) has been reported to be a suitable aquaculture species in Nigeria and other countries in Africa (Eyo et al. 2015) due to several favorable characteristics which include its ability \\ Springer Open}

(c) The Author(s). 2020 Open Access This article is licensed under a Creative Commons Attribution 4.0 International License, which permits use, sharing, adaptation, distribution and reproduction in any medium or format, as long as you give appropriate credit to the original author(s) and the source, provide a link to the Creative Commons licence, and indicate if changes were made. The images or other third party material in this article are included in the article's Creative Commons licence, unless indicated otherwise in a credit line to the material. If material is not included in the article's Creative Commons licence and your intended use is not permitted by statutory regulation or exceeds the permitted use, you will need to obtain permission directly from the copyright holder. To view a copy of this licence, visit http://creativecommons.org/licenses/by/4.0/. 
to tolerate a wide range of environmental conditions and high stocking densities under culture conditions, fast growth rate, acceptability of artificial feed, and high fecundity rate among others (Eyo et al. 2015). It is also popular with consumers in Nigeria for its highly nutritive values (Udeze et al. 2012).

Fish consumption is however not devoid of risks due to the possibility of them harboring infectious or pathogenic parasites particularly if such organisms are of zoonotic importance (Leal et al. 2008) owing to the fact that fish are sometimes cultured under potentially stressful conditions which may proliferate existing infections to become more severe and precipitate disease outbreaks, and these may compromise the fitness of such fish for human consumption (Danba et al. 2015). Therefore, this study sought to provide information on the parasitic loads of African catfish (C. gariepinus) from cultured and natural habitats.

\section{Methods}

\section{Study sites}

The study sites for this research were two fish-cultured ponds and two natural ponds. The fish-cultured ponds selected for this study were Ayodele fish pond (pond A) (latitude $7^{\circ} 17^{\prime} 50^{\prime \prime} \mathrm{N}$, longitude $5^{\circ} 9^{\prime} 0^{\prime \prime} \mathrm{E}$ ) and Abbey fish pond (pond B) (latitude $7^{\circ} 16^{\prime} 59^{\prime \prime} \mathrm{N}$, longitude $5^{\circ} 9^{\prime}$ $32^{\prime \prime}$ E). Both are located within Akure, a major city in Ondo State in South-western, Nigeria. The two natural habitats used were Owena reservoir (river A) (between latitude $7^{\circ} 15^{\prime} \mathrm{N}$, longitude $5^{\circ} 5^{\prime} \mathrm{E}$, and latitude $7^{\circ} 4^{\prime} \mathrm{N}$, longitude $4^{\circ} 47^{\prime}$ E) which is situated across Owena River located in the suburb of Owena town in Ifedore Local Government Area of Ondo-State and Igbokoda River (river B) (latitude $6^{\circ} 21^{\prime} \mathrm{N}$ and longitude $4^{\circ} 48^{\prime} \mathrm{E}$ ) situated in Igbokoda town is in Ilaje-Ese Odo, Ondo State.

\section{Ethics and consent}

The ethic and consent concerning the use of fish for this research were deemed unnecessary according to the Federal Institute of Industrial Research. Meanwhile, the experimental protocol including the number of fishes used for this research was approved and regulated by the Institute. In addition, all the methods were carried out in accordance with relevant guidelines.

\section{Sample collection and preparation}

A total number of 80 live adult African Catfish (C. gariepinus) of different weight range were purchased randomly from the above locations comprising of 20 samples from each of the locations, and they were transported live in a clean plastic keg containing water to the Biology Research Laboratory for further examinations. They were identified based on external features as described by Edeh and Solomon (2016).

\section{Sex determination}

Sexes of fish were identified by physical observation of the urogenital papillae located behind the anus which is long or distended in male, while in the female, it is round and reddish in the matured ones as described by Lagrue et al. (2011). These were later confirmed after dissection by visual observation of the testes in male and ovaries in the female. Prior to this, the fish were rendered inactive for easy handling.

\section{Measurements of length and weight}

The total length of the fish samples was taken from the tip of the snout to the extreme end of the caudal fin using a calibrated meter rule to the nearest centimeter $(\mathrm{cm})$ and recorded. Fish samples were also weighed to the nearest gram (g) using a manual weighing balance and recorded.

\section{Ectoparasite examination}

For the ectoparasites, external examination of the fish surface was first carried out by using hand lens for the detection of parasitic manifestation as described by Tachia et al. (2010). Subsequently, a sterile scalpel blade was used to scrape the skin from the head to the tail to obtain skin smear (mucus mixed with epidermal cells) which was placed in a sample plate containing $10 \mathrm{ml}$ of $0.9 \%$ saline solution and stirred using a mounted pin (Adeyemo and Falaye 2007; Ekanem et al. 2014). Drops of the mixed solution were collected using a dropper, placed on a clean slide, and examined under the $\times 10$ and $\times 40$ lenses of the binocular microscope (Olympus CX40). Detection of parasites from the gills of the sampled fish was made by using the methods described by Adeyemo and Falaye 2007, and Ekanem et al. 2014. The operculum was cut opened to expose the gills by using dissecting scissors, the exposed gills were detached, and the gill filaments and the gill arches were examined under the microscope.

\section{Endoparasite examination}

A cut was made on the ventral side of the fish from the anal opening to the lower jaw using a dissecting scissors to expose the body cavity and most of the internal organs. The stomach and intestine were separated and kept in different sample plates containing $0.9 \%$ saline solution. The contents of the stomach and intestine were washed in this normal saline solution for sedimentation and floatation. A drop of the residue was placed on the slide and the wet mount was examined for parasites under the microscope (Olympus CX40) using the $\times 10$ and $\times 40$ objectives for various parasites. The parasites were identified using a standard text by Ajala and Fawole (2014) and Kawe et al. 2016. The prevalence and intensity were calculated using the formulae below: 


$$
\text { Prevalence }(\%)=\frac{\text { Number of fish infected }}{\times 100}
$$

$$
\text { Intensity }=\frac{\text { Number of parasite }}{\text { Number of fish infected }}
$$

\section{Statistical analysis}

One sample $T$ test was used to calculate the significant difference between levels of infection in the two habitats while Carl Pearson chi-square test was used to determine the significant difference in parasite prevalence between the sexes and significance was taken at $P<0.05$. All analyses were done using Statistical Package for the Social Science (SPSS).

\section{Results}

\section{Prevalence of infection and intensity of parasites from} the studied habitats

The result presented in Table 1 showed that of the total 80 C. gariepinus examined, and a total of 43 (53.75\%) harbored different parasites. The prevalence of parasitic infection in river A (60\%) and river B (75\%) was significantly higher than that of pond A (45\%) and pond B (35\%) $(P<0.05)$. Generally, the total prevalence was higher in natural habitat (33.75\%) than the cultured habitat (20\%). However, the parasitic load (intensity) was slightly more in the cultured habitat (20.76) than the natural habitat (18.63\%).

\section{Parasitic loads from infected C. gariepinus}

The parasitic loads from infected C. gariepinus as presented in Table 2 showed that of the 409 parasites recovered from the infected catfishes, 141 (34.47\%) were ectoparasites while 268 (65.53\%) were endoparasites. Parasitic loads were observed to be significantly higher in natural habitat $(33.74 \%$ and $26.16 \%$ from river $\mathrm{A}$ and river $\mathrm{B}$, respectively) compared to cultured habitat (20.54\% and $19.55 \%$ from pond A and pond B, respectively). Similarly, the percentage ratio of endoparasite to ectoparasite was significantly higher in the natural habitat (40.83: 19.07) than the cultured habitat (24.69: $15.40)$. Generally, $65.53 \%(n=268)$ of the parasites recovered from the catfishes were endoparasites while $34.47 \%(n=141)$ were ectoparasites (Table 2$)$.

\section{Taxonomic classification of catfish parasites in cultured and natural habitats}

All the parasites obtained from this study (409) were observed to be distributed among five taxonomic groups of parasites namely nematoda, cestoda, trematoda, protozoa, and hirudinea (Table 3). The endoparasites obtained from catfishes include 4 nematodes (Caenorhabditis elegans, Philometroides africanus, Procamallanus spp., and Camallanus spp.), 3 cestodes (Monobothriodes woodlandi, Lytocestes marcuseni, and Spirometra reinacei), 3 trematodes (Clinostomum complanatum, Nesolecithus africanus, and Otodistomum spp), and 1 protozoon (Protoopalina symphysodonis). The catfish ectoparasites recovered include 1 hirudinean (Piscicola geometra), 2 trematodes (Gyrodactylus spp. and Dactylogyrus sp.), and 3 protozoans (Ichthyophithirius multiifiliis, Ichthyopthnous hoferi, and Epistylis spp). In addition, Otodistomum spp. and $M$. woodlandi were noted to be absent in pond A while Camallanus spp., N. africanus, S. reinacei, and P. geometra were absent in pond B (Table 3). Among the catfish parasites obtained from cultured habitat, Piscicola geometra had the highest species prevalence $(20 \%)$.

General overview of the catfish parasites in natural habitat showed that $C$. elegans, $P$. africanus, S. reinacei, and $L$. marcuseni were absent in river A but present in river B. Meanwhile, I. multiifiliis and I. hoferi were not encountered in catfishes obtained from river B. Of all the catfish parasites obtained in natural habitat, $P$. symphysodonis (25\%) and I. hoferi (20\%) had a higher prevalence compared to other catfish parasites obtained from natural habitat (Table 4).

Comparatively, Procamallanus spp., Camallanus spp., Datylogyrus spp., Gyrodactylus spp., Otodistomum spp., S. reinacei, and $L$. marcuseni were catfish parasites that are common to both cultured and natural habitats (Table 3). In contrast, $N$. africanus, Epistylis spp, $M$. woodlandi, and $P$. geometra are catfish parasites associated with cultured

Table 1 Prevalence and intensity of parasites from the cultured and natural habitats

\begin{tabular}{lllllll}
\hline Habitats & Locations & No. of fish examined & No. of fish infected & Prevalence (\%) & No. of parasite recovered & Intensity \\
\hline Cultured & Pond A & 20 & 9 & 45.00 & 84 & 9.33 \\
& Pond B & 20 & 7 & 35.00 & 80 & 11.43 \\
Subtotal & & 16 & 12 & 20.00 & 164 & 20.76 \\
Natural & River A & 20 & 15 & 60.00 & 138 & 11.50 \\
& River B & 20 & 27 & 75.00 & 107 & 7.13 \\
Subtotal & & 40 & 43 & 33.75 & 245 & 18.63 \\
Total & 80 & & 53.75 & 409 & 9.51 \\
\hline
\end{tabular}

$t=6.131, P=0.009, \mathrm{df}=3$ 
Table 2 Comparison of the catfish parasites in natural and cultured habitats

\begin{tabular}{lllll}
\hline Habitats & Locations & \multicolumn{2}{l}{ Parasites recovered } & Total (\%) \\
\cline { 3 - 4 } & & Ectoparasites (\%) & Endoparasites (\%) & $84(20.54)$ \\
\hline Cultured & Pond A & $28(33.30)$ & $56(66.70)$ & $80(19.55)$ \\
& Pond B & $35(43.80)$ & $45(56.30)$ & $164(40.09)$ \\
Subtotal & & $63(15.40)$ & $101(24.69)$ & $138(33.74)$ \\
Natural & River A & $56(40.60)$ & $82(59.40)$ & $107(26.16)$ \\
& River B & $22(20.60)$ & $85(79.40)$ & $245(59.90)$ \\
Subtotal & & $78(19.07)$ & $167(40.83)$ & $409(100.0)$ \\
Total & & $141(34.47)$ & $268(65.53)$ &
\end{tabular}

$t=7.669, P=0.005, \mathrm{df}=3$

habitat, while C. elegans, P. africanus, C. complanatum, $P$. symphysodonis, I. multiifillis, and I. hoferi were only found in natural habitat (Table 4).

\section{Prevalence of parasites in relation to the sex of $C$. gariepinus}

Table 5 showed the prevalence of parasites in both male and female $C$. gariepinus sampled from cultured and natural habitat. The obtained results showed that the prevalence was higher in female compared to male except in pond A which the prevalence recorded was higher in male C. gariepinus (55.56\%) than female (36.37\%). Meanwhile, chi-square analysis of the data on sex showed no significant difference in prevalent rates between male and female $C$. gariepinus $(P>0.05)$.

\section{Distribution of ectoparasites in relation to sites of infection in infected $C$. gariepinus}

Distributions of ectoparasites in relation to the site of infection in C. gariepinus were presented in Table 6. The results showed that more ectoparasites were observed on the skin $(n=93)$ compared to the gills $(n=48)$ of infected C. gariepinus (Table 6). Three ectoparasites were recovered from the gills (Ichthyopthnous hoferi, Dactylogyrus spp., and Gyrodactylus spp.) while six ectoparasites which include Ichthyophithirius multiifiliis, I. hoferi, Piscicola geometra, Dactylogyrus spp, Epistylis spp., and Gyrodactylus spp. were recovered from the skin of the fish.

\section{Distribution of endoparasites in relation to sites of infection in infected C. gariepinus.}

Distributions of endoparasites in relation to sites of infection in C. gariepinus were presented in Table 7 . The results showed that 268 endoparasites were recovered from the stomach and intestines of infected catfishes. The result further showed that the catfish intestines $(n=$ $140)$ were more infected than the stomach $(n=128)$. Out of the 11 species of endoparasites observed in catfishes, $N$. africanus was absent in the fish intestine while

Table 3 Catfish parasites in cultured habitat

\begin{tabular}{|c|c|c|c|c|c|c|c|}
\hline \multirow[t]{2}{*}{ Group } & \multirow{2}{*}{$\begin{array}{l}\text { Parasite } \\
\text { Species }\end{array}$} & \multicolumn{3}{|l|}{ Pond A } & \multicolumn{3}{|l|}{ Pond B } \\
\hline & & $\begin{array}{l}\text { No. of fish } \\
\text { infected }\end{array}$ & $\begin{array}{l}\text { Species } \\
\text { prevalence (\%) }\end{array}$ & $\begin{array}{l}\text { No. of parasite } \\
\text { recovered }\end{array}$ & $\begin{array}{l}\text { No. of fish } \\
\text { infected }\end{array}$ & $\begin{array}{l}\text { Species } \\
\text { prevalence (\%) }\end{array}$ & $\begin{array}{l}\text { No. of parasite } \\
\text { recovered }\end{array}$ \\
\hline \multirow[t]{2}{*}{ Nematoda } & $\begin{array}{l}\text { Procamallanus } \\
\text { spp }\end{array}$ & 3 & 15 & 9 & 2 & 10 & 18 \\
\hline & Camallanus spp & 2 & 10 & 23 & 0 & 0 & 0 \\
\hline \multirow[t]{4}{*}{ Trematoda } & N. africanus & 2 & 10 & 16 & 0 & 0 & 0 \\
\hline & $\begin{array}{l}\text { Otodistomum } \\
\text { spp }\end{array}$ & 0 & 0 & 0 & 2 & 10 & 7 \\
\hline & $\begin{array}{l}\text { Dactylogyrus } \\
\text { spp }\end{array}$ & 1 & 5 & 4 & 2 & 10 & 6 \\
\hline & Gyrodactylus spp & 2 & 10 & 5 & 2 & 10 & 7 \\
\hline Protozoan & Epistylis spp & 1 & 5 & 6 & 3 & 15 & 22 \\
\hline \multirow[t]{3}{*}{ Cestoda } & M. woodlandi & 0 & 0 & 0 & 2 & 10 & 14 \\
\hline & S. reinacei & 1 & 5 & 3 & 0 & 0 & 0 \\
\hline & L. marcuseni & 1 & 5 & 5 & 1 & 5 & 6 \\
\hline Hirudinea & P. geometra & 4 & 20 & 13 & 0 & 0 & 0 \\
\hline
\end{tabular}


Table 4 Catfish parasites in natural habitat

\begin{tabular}{|c|c|c|c|c|c|c|c|}
\hline \multirow{2}{*}{$\begin{array}{l}\text { Taxonomic } \\
\text { group }\end{array}$} & \multirow[t]{2}{*}{ Parasite species } & \multicolumn{3}{|l|}{ River $\mathrm{A}$} & \multicolumn{3}{|l|}{ River B } \\
\hline & & $\begin{array}{l}\text { No. of fish } \\
\text { infected }\end{array}$ & $\begin{array}{l}\text { Species } \\
\text { prevalence (\%) }\end{array}$ & $\begin{array}{l}\text { No. of parasite } \\
\text { recovered }\end{array}$ & $\begin{array}{l}\text { No. of fish } \\
\text { infected }\end{array}$ & $\begin{array}{l}\text { Species } \\
\text { prevalence (\%) }\end{array}$ & $\begin{array}{l}\text { No. of parasite } \\
\text { recovered }\end{array}$ \\
\hline \multirow[t]{4}{*}{ Nematoda } & C. elegans & 0 & 0 & 0 & 4 & 20 & 19 \\
\hline & P. africanus & 0 & 0 & 0 & 2 & 10 & 8 \\
\hline & $\begin{array}{l}\text { Procamallanus } \\
\text { spp }\end{array}$ & 2 & 10 & 10 & 4 & 20 & 12 \\
\hline & Camallanus spp & 3 & 15 & 15 & 2 & 10 & 5 \\
\hline \multirow[t]{4}{*}{ Trematoda } & C. complanatum & 2 & 10 & 12 & 2 & 10 & 16 \\
\hline & $\begin{array}{l}\text { Otodistomum } \\
\text { spp }\end{array}$ & 0 & 0 & 0 & 1 & 5 & 3 \\
\hline & Dactylogyrus spp & 2 & 10 & 7 & 4 & 20 & 15 \\
\hline & Gyrodactylus spp & 3 & 15 & 12 & 2 & 10 & 7 \\
\hline \multirow[t]{3}{*}{ Protozoa } & P.symphysodonis & 5 & 25 & 38 & 2 & 10 & 6 \\
\hline & 1. multiifiliis & 2 & 10 & 13 & 0 & 0 & 0 \\
\hline & I. hoferi & 4 & 20 & 24 & 0 & 0 & 0 \\
\hline \multirow[t]{3}{*}{ Cestoda } & M. woodlandi & 2 & 10 & 7 & 2 & 10 & 11 \\
\hline & S. reinacei & 0 & 0 & 0 & 1 & 5 & 2 \\
\hline & L. marcuseni & 0 & 0 & 0 & 1 & 5 & 3 \\
\hline
\end{tabular}

Otodistomum spp. was absent in the fish stomach (Table 7). In terms of the total number of parasites recovered, Procamallanus spp. $(n=49)$, P. symphysodonis $(n=44)$, and Camallanus spp. $(n=43)$ were the most abundant endoparasites in C. gariepinus (Table 7). Similarly, of the 52 infected catfishes, 10 of them were infected with Procamallanus spp., 6 catfishes were infected with $M$. woodlandi, P. symphysodonis and Camallanus spp., 2 catfishes were infected with $P$. africanus, $S$. reinacei, and N. africanus (Table 7).

\section{Prevalence of parasites in relation to the body weight of infected C. gariepinus}

The results of parasite prevalence in relation to the body weight as presented in Tables 8 and 9 showed that catfishes obtained from both cultured and natural habitats with body weight 500-599g had the highest prevalence
(100\%) while no parasite $(0 \%)$ was observed in catfishes obtained from a natural habitat with body weight 200$299 \mathrm{~g}$ and $700-799 \mathrm{~g}$. Parasite is only absent in catfishes with body weight $700-799 \mathrm{~g}$ obtained from pond B of the natural habitat.

\section{Discussion}

The results of this work reveal the presence of parasites in C. gariepinus from cultured and natural habitats under study. Findings indicated a higher prevalence of $33.75 \%$ of catfish parasites in natural habitat compared to a low prevalence of $20 \%$ observed in cultured habitat. Higher prevalence recorded from natural habitat may be due to many factors such as feeding habit of fish, pollution of water bodies, and availability of intermediate hosts (copepods, insects, molluscs, etc.) which harbor the infective larval stage of some of these parasites

Table 5 Prevalence of parasites in relation to the sex of C. gariepinus

\begin{tabular}{|c|c|c|c|c|c|c|c|}
\hline Habitat & Location & Sex & No. of fish examined & No. of fish infected & Prevalence (\%) & $x^{2}$ & $P$ value \\
\hline \multirow[t]{4}{*}{ Cultured } & Pond A & Male & 9 & 5 & 55.56 & 0.74 & 0.39 \\
\hline & & Female & 11 & 4 & 36.37 & & \\
\hline & Pond B & Male & 11 & 3 & 27.27 & 0.64 & 0.42 \\
\hline & & Female & 9 & 4 & 44.44 & & \\
\hline \multirow[t]{4}{*}{ Natural } & River A & Male & 7 & 4 & 57.14 & 0.04 & 0.85 \\
\hline & & Female & 13 & 8 & 61.54 & & \\
\hline & River B & Male & 12 & 8 & 66.67 & 1.11 & 0.29 \\
\hline & & Female & 8 & 7 & 87.50 & & \\
\hline Total & & & 80 & 43 & 53.75 & & \\
\hline
\end{tabular}


Table 6 Distribution of ectoparasites in relation to the site of infection on infected C. gariepinus

\begin{tabular}{|c|c|c|c|c|c|c|}
\hline \multirow{2}{*}{$\begin{array}{l}\text { Parasite } \\
\text { species }\end{array}$} & \multirow{2}{*}{$\begin{array}{l}\text { No. of } \\
\text { fish } \\
\text { infected }\end{array}$} & \multirow{2}{*}{$\begin{array}{l}\text { Prevalence } \\
\text { (\%) }\end{array}$} & \multicolumn{2}{|c|}{ Site of infection } & \multirow{2}{*}{$\begin{array}{l}\text { Total no. } \\
\text { of } \\
\text { parasites }\end{array}$} & \multirow[t]{2}{*}{ Intensity } \\
\hline & & & Gills & Skin & & \\
\hline I. multiifiliis & 2 & 2.5 & 0 & 13 & 13 & 6.5 \\
\hline I. hoferi & 4 & 5.0 & 18 & 6 & 24 & 6.0 \\
\hline P. geometra & 4 & 5.0 & 0 & 13 & 13 & 3.3 \\
\hline Dactylogyrus spp. & 10 & 12.5 & 23 & 10 & 32 & 3.6 \\
\hline Epistylis spp. & 4 & 5.0 & 0 & 28 & 28 & 7.0 \\
\hline Gyrodactylus spp. & 8 & 10.0 & 7 & 23 & 31 & 3.4 \\
\hline Total & 32 & 40.0 & 48 & 93 & 141 & 4.4 \\
\hline
\end{tabular}

making them available to fish in the water (Kawe et al. 2016). Also, Hoffman (1998) stated that wild populations of animals have greater parasite species diversity due to larger home ranges compared to domesticated ones. Meanwhile, the low prevalence recorded from cultured habitat may imply that there have been an improvement in management practices of cultured fish such as the reduction in overcrowding of fish ponds carried out by a fish farmer in these study areas (Ayanda 2009) and the use of screen net around fish ponds to guide against piscivorous birds which may serve as host to some of these parasites and can disseminate parasite eggs to fish ponds (Aliyu and Solomon 2012). The high prevalence of fish parasites recorded in the research agrees with the work of Onyedineke et al. (2010) who reported a high prevalence $(59.2 \%)$ of parasites from fish obtained from the river at Illushi, Edo State, Nigeria, and with Kawe et al. (2016) who recorded high prevalence (67.5\%) of gastrointestinal helminth parasites of C. gariepinus in Abuja, Nigeria. However, the result is in contrast to the findings of Anosike et al. (1992) who reported heavy infection of $52 \%$ for cultured and $34.7 \%$ for wild C. gariepinus in Plateau State (Ayanda 2009).

However, the presence of parasites in C. gariepinus sampled from cultured habitat used for this study, although with low prevalence may be due the introduction of unexamined C. gariepinus obtained from the wild directly into fish ponds or the presence of parasites in the parent stock. Oniye et al. (2004) suggested the incorporation of antihelminthic therapy into the diet of C. gariepinus obtained from the wild that might be used as broodstocks. Also, Yakubu et al. (2002) suggested that when fish are to be stocked from wild, they should be kept under good hygienic conditions in quarantine ponds and treated with recommended chemicals for at least $1-2$ weeks to eliminate any stage of parasites.

The parasites recovered from different body parts of C. gariepinus used for this study have been previously recorded by other researchers (Imam and Dewu 2010; Keremah and Inko-Tariah 2013; Eyo et al. 2014; Uruku

Table 7 Distribution of endoparasites in relation to the site of infection in infected C. gariepinus

\begin{tabular}{|c|c|c|c|c|c|c|}
\hline \multirow[t]{2}{*}{ Parasite species } & \multirow{2}{*}{$\begin{array}{l}\text { No. of } \\
\text { fish } \\
\text { infected }\end{array}$} & \multirow{2}{*}{$\begin{array}{l}\text { Prevalence } \\
\text { (\%) }\end{array}$} & \multicolumn{2}{|c|}{ Site of infection } & \multirow{2}{*}{$\begin{array}{l}\text { Total no. } \\
\text { of } \\
\text { parasites } \\
\text { recovered }\end{array}$} & \multirow[t]{2}{*}{ Intensity } \\
\hline & & & Stomach & Intestines & & \\
\hline C. elegans & 4 & 5.00 & 2 & 17 & 19 & 4.8 \\
\hline P. africanus & 2 & 2.50 & 5 & 3 & 8 & 4.0 \\
\hline C. complanatum & 4 & 5.00 & 12 & 16 & 28 & 7.0 \\
\hline P. symphysodonis & 6 & 7.50 & 21 & 23 & 44 & 7.3 \\
\hline S. reinacei & 2 & 2.50 & 2 & 3 & 5 & 1.3 \\
\hline Procamallanus spp. & 10 & 12.50 & 25 & 26 & 49 & 4.9 \\
\hline M. woodlandi & 6 & 7.50 & 18 & 14 & 32 & 5.3 \\
\hline Camallanus spp. & 6 & 7.50 & 18 & 25 & 43 & 7.2 \\
\hline L. marcuseni & 3 & 3.75 & 3 & 11 & 14 & 4.7 \\
\hline N. africanus & 2 & 2.50 & 16 & 0 & 16 & 8.0 \\
\hline Otodistomum spp. & 3 & 3.75 & 0 & 10 & 10 & 3.3 \\
\hline Total & 52 & 65.00 & 128 & 140 & 268 & 5.0 \\
\hline
\end{tabular}


Table 8 Prevalence of parasites in relation to body weight of natural C. gariepinus

\begin{tabular}{|c|c|c|c|c|c|c|}
\hline \multirow{2}{*}{$\begin{array}{l}\text { Body } \\
\text { weight } \\
\text { (g) }\end{array}$} & \multicolumn{3}{|l|}{ River A } & \multicolumn{3}{|l|}{ River B } \\
\hline & No. of fish examined & No. of fish infected & Prevalence (\%) & No. of fish examined & No. of fish infected & Prevalence (\%) \\
\hline $200-299$ & 3 & 1 & 33.33 & 1 & 0 & 0.00 \\
\hline $300-399$ & 3 & 1 & 33.33 & 3 & 1 & 33.33 \\
\hline $400-499$ & 5 & 3 & 60.00 & 9 & 8 & 88.89 \\
\hline $500-599$ & 6 & 5 & 83.33 & 5 & 5 & 100.00 \\
\hline 600-699 & 3 & 2 & 66.66 & 2 & 1 & 50.00 \\
\hline 700-799 & 0 & 0 & 0.00 & 0 & 0 & 0.00 \\
\hline Total & 20 & 12 & 60.00 & 20 & 15 & 75.00 \\
\hline
\end{tabular}

and Adikwu 2017). In terms of the number of parasite recovered from the catfishes, Camallanus spp. was the most abundant in cultured habitat while P. symphysodonis was the most abundant in natural habitat. However, there was no single species of Acanthocephalan recorded in this study which may be majorly due to absence of suitable intermediate host required for transmission although, some earlier works such as Balarin 1979; Onwuliri and Mgbemena 1987 reported that Acanthocephalan was the commonest parasites of fresh water fish in the tropics.

In addition, Imevbore and Bakare (1970) reported that Clarias species are bottom dwellers, which feed on what is most available and close to them such as detritus, water invertebrates like arthropods, molluscs, and mud, and among these invertebrates, there may be intermediate hosts of various parasites which may develop into adults in the gut of fish after consumption. The recovery of these species of parasites in this study could also have serious physiological consequences as they interfere with the absorption of food nutrients in the fish intestines, similar observation was made by other authors (Biu et al. 2014; Iboh and Ajang 2016). The authors added that such interference could reduce the food intake of fishes.

The prevalence of catfish parasites in relation to sexes as reported by this study was not significant. This finding was a deviation from the study of other authors. For instance, a higher prevalence of parasites in female $C$. gariepinus compared to male has been reported by Omeji et al. 2013 and Ogonna et al. 2017. Both authors recorded higher parasitic infections in female compared to male. Similar reports of Ayanda 2009 and Emere 2000 at different locations reported higher parasitic infections in female species than the males. In addition, Emere and Egbe (2006) also reported higher infection in females than males and suggested that it could be due to the physiological state of the females as most gravid females could have reduced resistance to infection by parasites; this is because the immune system of the females is highly compromised during pregnancy. Omeji et al. (2013) noted that female fish need increased food intake to meet their food requirements for the development of eggs and that this may have exposed them to more contact with the parasites, which subsequently increased their chance of being infected. In contrast, the report of Oniye et al. (2004) recorded a higher prevalence of infection in male $(15.0 \%)$ than the female catfishes $(4.17 \%)$ and Tachia et al. (2010) also recorded higher infection in males (65.12\%) than the females (34.89\%). Generally, feeding in catfishes is attributed to their quest for survival and differential feeding either by quantity or quality of food and not by sexes (Ogonna et al. 2017). The present study revealed that the skin and intestines harbored the highest number of ectoparasites (93) and endoparasites (140), respectively. This could be due to the

Table 9 Prevalence of parasites in relation to the body weight of cultured C. gariepinus

\begin{tabular}{|c|c|c|c|c|c|c|}
\hline \multirow{2}{*}{$\begin{array}{l}\text { Body } \\
\text { weight } \\
\text { (g) }\end{array}$} & \multicolumn{3}{|l|}{ Pond A } & \multicolumn{3}{|l|}{ Pond B } \\
\hline & No. of fish examined & No. of fish infected & Prevalence (\%) & No. of fish examined & No. of fish infected & Prevalence (\%) \\
\hline $200-299$ & 3 & 1 & 33.33 & 3 & 1 & 33.33 \\
\hline 300-399 & 2 & 0 & 0.00 & 6 & 2 & 33.33 \\
\hline 400-499 & 3 & 1 & 33.33 & 6 & 0 & 0.00 \\
\hline $500-599$ & 4 & 2 & 50.00 & 3 & 3 & 100.00 \\
\hline $600-699$ & 4 & 2 & 50.00 & 2 & 1 & 50.00 \\
\hline $700-799$ & 4 & 3 & 75.00 & 0 & 0 & 0.00 \\
\hline Total & 20 & 9 & 45.00 & 20 & 7 & 35.00 \\
\hline
\end{tabular}


conducive nutritional advantage presented by the host's intestine to the parasites; this observation corroborates with the works of Aliyu and Solomon (2012) and Onyedineke et al. (2010) who reported the highest number of parasites in the intestine from C. gariepinus obtained from lower Usman Dam, Abuja, and River Niger at Illushi Edo State, respectively. The preference of parasites for the intestines compared to the stomach may also be due to the presence of digested food present in the intestines and greater surface area of the intestines as suggested by Dan-kishiya and Oboh (2013) while Ajala and Fawole (2014) argued that the presence of an acidic medium in the stomach may render the stomach unfavorable for these parasites. Also, the peristaltic movement of the stomach muscle during digestion may also hinder the proliferation of parasites in the stomach as opined by Akinsanya and Hassan (2008).

More ectoparasites were recorded from the skin of $C$. gariepinus than the gills. This result agrees with the report of Tachia et al. (2010), who observed more ectoparasites on the skins of C. gariepinus caught from the University of Agriculture Research Fish Farm. The author suggested that the skin is easily accessible by these parasites due to direct contact of the skin with the surrounding water or continuous movement of water over the skin. This report is contrary to the findings of Emere and Egbe (2006) and Omeji et al. (2011) who reported a higher number of parasites in the gills compared to the skin. The authors concluded that the gills are the center of filter-feeding and also an important site used for gaseous exchange in fish. Somerviille (1984) also noted that the sieving ability of the gill rakers may help to trap some parasites.

A higher rate of parasitic infection was observed in the larger size of $C$. gariepinus than the smaller ones across the two habitats. An increase in size as postulated by Oniye et al. (2004) is an indication of an increase in length and weight of fish and this can also be considered as a measure of age. Therefore, this observation may be attributed to the fact that larger size C. gariepinus provide a larger surface area for parasitic infection than the smaller ones and the ability of larger size fish to cover wide areas in search of food, and as a result of these, they take in more food than smaller ones which may expose them to parasitic infections (Tachia et al. 2010; Omeji et al. 2013; Bichi and Dawaki 2010). Bichi and Dawaki (2010) reported that the prevalence was found to increase as the fish grows and could be attributed to the longer time of exposure to the environment by body size. In relation to this observation, Reed et al. (1987) stated that there is a change in the diet of juvenile Clarias spp. from weeds, seeds, phytoplankton, and zooplankton to insect larvae, snails, crustaceans, worms, and smaller fish as adulthood is attained.

\section{Conclusions}

This study revealed the presence of parasites in the two habitats under study. The parasites recovered were found to belong to Nematoda, Cestoda, Trematoda, Protozoan, and Hirudinea taxonomic group. Both habitats were noted to be infected; however, the natural habitat was more infected than the cultured habitat. Also, C. gariepinus of larger size were more infected compared to a smaller size. Based on this study, it is therefore important that the sanitary conditions under which fish are reared in fish ponds should be improved through the use of quality water free of contamination. Likewise, vegetation surrounding fish ponds should be reduced in order to eliminate potential intermediate host. Fish from unscreened sources should not be introduced directly into fish ponds but rather be quarantined to eliminate possible parasitic infection especially fish from natural habitats. Also, fish farmers and sellers should be enlightened on the potential risk of parasitic infection in fish in order to avoid economic loss and most importantly, fish should be properly cooked before consumption so as to destroy parasite harbored.

\section{Abbreviations}

C. gariepinus: Clarias gariepinus; C. elegans: Caenorhabditis elegans; C. complanatum: Clinostomum complanatum; FAO: Food and Agriculture Organization; I. multiifiliis: Ichthyophithirius multifiliis; I. hoferi: Ichthyopthnous hoferi; L. marcuseni: Lytocestes marcuseni; M. woodlandi: Monobothriodes woodlandi; N. africanus: Nesolecithus africanus; P. geometra: Piscicola geometra; P. africanus: Philometroides africanus; P. symphysodonis: Protoopalina symphysodonis; S. reinacei: Spirometra reinacei

\section{Acknowledgements}

The authors acknowledged the contribution of the fishermen in Owena and Igbokoda Rivers in capturing the catfishes used for this research. The authors are also grateful to Mrs. E.T. Ojo, the chief technologist of the Department of Biology, Federal University of Technology Akure, Nigeria, for her technical assistance during the laboratory work.

\section{Authors' contributions}

OJA and OOO involved in the study design. OJA and FCO involved in the field and the laboratory works. Data analysis was undertook by the authors OJA and FCO. OJA and FCO were the major contributors in writing the manuscript. The authors read and approved the final manuscript.

\section{Funding}

No funding was obtained for this study.

\section{Availability of data and materials}

All data generated or analyzed during this study are included in this published article [and its supplementary information files].

\section{Ethics approval and consent to participate}

The ethic and consent concerning the use of fish for this research were deemed unnecessary according to the Federal Institute of Industrial Research.

\section{Consent for publication}

The authors gave their consent to the Bulletin of the National Research Centre to publish this manuscript if accepted for publication in the Bulletin of National Research Centre.

Competing interests

The authors declare that they have no competing interests. 
Received: 4 February 2020 Accepted: 8 September 2020

Published online: 18 September 2020

\section{References}

Adeyemo AO, Falaye AE (2007) Parasitic incidence in cultured Clarias gariepinus. An Res Int 4(2):702-704

Aihonsu JO, Jimoh SB, Banwo A (2006) Economic analysis of commercial fish farming in ljebu and Remo Divisions of Ogun State, Nigeria. Ogun J Agric Sci 4:1-11

Ajala OO, Fawole $\mathrm{OO}$ (2014) Multiple infections of Helminths in the alimentary system of Clarias gariepinus (Burchell, 1822) in a tropical reservoir. Int J Fisheries Aquacult 6(6):62-70

Akinsanya B, Hassan AA, Adeogun AO (2008) Gastrointestinal Helminths of fish Synodontis clarias (Siluriformes: Mochokidae) from Lekki Lagoon, Lagos, Nigeria. Int J Trop Biol 56(4):2021-2026

Aliyu MD, Solomon JR (2012) The intestinal parasite of Clarias gariepinus found at lower Usman Dam, Abuja. Researcher 4(9):38-44

Anosike JC, Omoregie E, Ofojekwu PC, Nweke IE (1992) A survey of helminth parasites of Clarias gariepinus in Plateau State, Nigeria. J Aquat Sci 7:39-43

Ayanda OI (2009) Comparative parasitic helminth infection between cultured and wild species of Clarias gariepinus in Ilorin, North Central Nigeria. Sci Res Essay 4(1):18-21

Balarin JD (1979) Tilapia - a guide to their biology and culture in Africa. University of Stirling, Scotland

Bichi AH, Dawaki SS (2010) A survey of the ectoparasites on the gills, skin and fins of Oreochromis niloticus at Bagauda fish farm, Kano, Nigeria. Bayero J Pure Appl Sci 3(1):83-86

Biu AA, Diyaware MY, Yakaka W, Rita DJ (2014) Incidence of parasites of Clarias gariepinus (Burchell, (1822)) caught from lake Alau, Maiduguri, Borno State, Nigeria. Nig J Fish Aquacult 2(1):74-80

Danba EP, David DL, Wahedi JA, Buba U, Bingari MS, Umaru FF, Ahmed MK, Tukur KU, Barau BW, Dauda UD, Thomas TL (2015) Microbiological analysis of selected catfish ponds in Kano metropolis, Nigeria. J Agricult Vet Sci 8(8):74-78

Dan-kishiya AS, Oboh A, Usman BI (2013) The prevalence of Helminth parasites in the gastro-intestinal tract of wild African sharptooth catfish Clarias gariepinus (Siluriformes: Clariidae) in Gwagwalada, Nigeria. Research J Costa Rican Distance Educ Univ 5(1):83-87

Edeh C, Solomon RJ (2016) Endoparasites of Oreochromis niloticus and Clarias gariepinus found in Utako flowing gutter, Direct Research Journal of Agricultural Food Science. 4(12):361-373

Ekanem AP, Eyo VO, Udoh JP, Okon JA (2014) Endoparasites of food-fish landing from the Calabar River, Cross River State, Nigeria. J Sci Res Rep 3(6):810-817

Emere MC (2000) Parasitic infection of the Nile Perch Lates niliticus in River Kaduna. J Aquat Sci 15:51-54

Emere MC, Egbe NE (2006) Protozoan parasites of Synodontis clarias (A freshwater fish) in river Kaduna. BEST J 3(3):58-64

Eyo VO, Edet TA, Ekanem AP (2015) Monogenean parasites of the African catfish Clarias gariepinus from two fish farms in Calabar, Cross River State, Nigeria. J Coastal Life Med 3(6):433-437

Eyo VO, Ekanem AP, Jimmy UI (2014) A comparative study of the gonadosomatic index (GSI) and gonad gross morphology of African catfish (Clarias gariepinus) fed unical aqua feed and Coppens commercial feed. Croatian J Fish 72(2):63-69

FAO (Food and Agriculture Organization) (1996) Aquaculture potential in African documentation issued on the occasion of the World Food Summit in Rome November Rome FAO, p 20

Hoffman GL (ed) (1998) Parasites of north american freshwater fishes. Cornell University Press, Ithaca, New York

Iboh Cl, Ajang RO (2016) Helminths parasitic infection of Clarias gariepinus from great kwa river, Cross river State, Nigeria. Eur J Pharmaceut Med Res 3(12): 101-105

Imam TS, Dewu RA (2010) Survey of Piscine ecto and intestinal parasites of Clarias spp sold at Galadima road fish market, Kano metropolis, Nigeria. Biosci Res Comm 22(4):209-212

Imevbore AM, Bakare O (1970) The food and feeding habits of non-cichlid fishes of the River Niger in the Kanji Reservoir area. In: Visser SA (ed) Kanji: a Nigerian man-made lake. Kanji Lake studies and Ecology, vol 1. Nigerian Institute of Social and Economic Research, Ibadan, pp 49-64

Kawe SM, God'spower RO, Balarabe MR, Akaniru RI (2016) Prevalence of gastrointestinal helminth parasites of Clarias gariepinus in Abuja, Nigeria. Sokoto J Vet Sci 14(2):26-33
Keremah RI, Inko-Tariah MB (2013) Comparative study of ectoparasites on Nile tilapia (Oreochromis niloticus) cultured under integrated and unintegrated pond systems. Afr J Biotechnol 12(19):2711-2714

Lagrue C, Kelly DW, Hicks A, Poulin R (2011) Factors influencing infection patterns of trophically transmitted parasites among a fish community: host diet, host - parasite compatibility or both? Fish Biol 79:466-485

Leal DA, Pereira MA, Franco RM, Branco N, Neto RC (2008) First report of Cryptosporidium spp oocysts in oysters (Crassostrea rhizophorae) and cockles (Tivela mactroides) in Brazil. J Water Health 6(4):527-532

Ogonna CA, Emmanuel IN, Michael DA (2017) Survey of ectoparasites of cultured fish from selected farms in Ebonyi State: potential for food and nutrient security. Int J Res Pharm Biosci 4(7):1-6

Omeji S, Solomon SG, Idoga ES (2011) A comparative study of the common protozoan parasites of Clarias gariepinus from the wild and cultured environments in Benue State, Nigeria. J Parasitol Res:1-8

Omeji S, Solomon SG, Uloko C (2013) Comparative study on the endo-parasitic infestation in Clarias gariepinus collected from earthen and concrete ponds in Makurdi, Benue, State, Nigeria. J Agricult Vet Sci 2(1):45-50

Oniye SJ, Adebote DA, Ayanda OI (2004) Helminth parasites of Clarias gariepinus in Zaria, Nigeria. J Aquat Sci 19(2):71-76

Onwuliri CO, Mgbemena MO (1987) The parasitic fauna of some freshwater fish from Jos Plateau, Nigeria. Nig J Appl Fish Hydrobiol 2:33-37

Onyedineke NE, Obi U, Ofoegbu P, Okogo I (2010) Helminth parasites of some freshwater fish from River Niger at llushi, Edo State. Nig J An Sci 6(3):11-15

Osuigwe DI, Obiekezie Al (2007) Assessment of the growth performance and feed utilization of fingering Heterobranchus longifilis fed raw and boiled jackbean (Canavalia ensiformis) seed meal as fishmeal substitute. J Fish Int 2: $37-41$

Reed WB, Jopson JI, Ibrahim Y (1987) Fish and fishes of Northern Nigeria. Zaria, Nigeria, pp 123-140

Somerviille C (1984) Some economic aspects of common parasites in culture fish: disease and health control of farmed fish (including shellfish and crustaceans) in Europe, pp 123-130

Tachia MU, Omeji S, Odeh L (2010) A survey of ectoparasites of Clarias gariepinus caught from the University of Agriculture Research fish farm, Makurdi. J Res Forestry Wildlife Env 4(2):30-37

Udeze ON, Talatu M, Ezediokpu MN, Nwanze JC, Onoh C, Okonko IO (2012) The effect of Klebsiella pneumoniae on catfish (Clarias gariepinus). Researcher 4(4): $51-59$

Uruku MN, Adikwu IA (2017) Seasonal prevalence of parasites of clariids fishes from the lower Benue River, Nigeria. Nig J Fish Aquacult 5(2):11-19

Yakubu DP, Omoregie E, Wade JW, Faringoro DU (2002) A comparative study of gut helminths of Tilapia Zilli and Clarias gariepinus from river Uke, Plateau State, Nigeria. J Aquat Sci 17(2):137-139

\section{Publisher's Note}

Springer Nature remains neutral with regard to jurisdictional claims in published maps and institutional affiliations.

\section{Submit your manuscript to a SpringerOpen ${ }^{\circ}$ journal and benefit from:}

- Convenient online submission

- Rigorous peer review

- Open access: articles freely available online

- High visibility within the field

- Retaining the copyright to your article

Submit your next manuscript at $\boldsymbol{\nabla}$ springeropen.com 